\title{
FREI BETTO EM EXPERIÊNCIAS DE VIAGENS: O CRISTÃO NO SOCIALISMO REAL ${ }^{1}$
}

\author{
Rhaissa Marques Botelho Lobo² \\ lattes.cnpq.br/7004702000424408
}

Resumo: Analisam-se aqui as incursões e trabalhos pastorais nos países do socialismo real especialmente Cuba, Nicarágua, União Soviética e as reflexões que ele faz entre convergências e divergências da teoria marxista e a religião cristã.

Palavras-chave: Viagens; Frei Betto; Teologia da Libertação; Intelectual; Socialismo.

\section{FREI BETTO IN TRAVEL EXPERIENCES: THE CHRISTIAN IN REAL SOCIALISM}

\begin{abstract}
This paper examines the incursions and pastoral work in the countries of real socialism, especially Cuba, Nicaragua, Soviet Union, and the reflections he makes between the convergences and divergences of Marxist theory and the christian religion.
\end{abstract}

Keywords: Travel; Frei Betto; Liberation Theology; Intellectual; Socialism.

Frei Betto analisa as experiências e vivências dos cristãos nos países socialistas reais. As obras "Cristianismo e marxismo" e "O paraíso perdido: nos bastidores do socialismo" são consequências de um projeto inicial do autor, em 1979, que passou a ter formas reais a partir da publicação de "Fidel e a religião: conversas com Frei Betto". O próprio autor enunciou, no prefácio denominado "Caminhos de um encontro", que a ideia inicial nascera em conversa com o editor Ênio Silveira e projetava uma série de viagens cuja problemática central era focada na relação entre comunidades

\footnotetext{
${ }^{1}$ Este texto é uma versão do terceiro capítulo - Frei Betto: reflexões sobre o marxismo e socialismo - da minha dissertação, onde analiso os diálogos teóricos e práticos entre o cristianismo da libertação de Frei Betto e a teoria marxista.

2 Mestre em História. Docente da Universidade Federal de Mato Grosso (Brasil). Contato: $\underline{\text { rh_aissa@hotmail.com. }}$
} 
cristãs e regimes que qualificavam a si próprios como materialistas e ateus (BETTO, 1985, p. 11).

"Fidel e a religião: conversas Com Frei Betto" resultou de 23 horas de entrevista, na qual Fidel Castro respondeu às perguntas de Frei Betto sobre questões religiosas, econômicas, políticas. O livro demonstra as relações entre cristianismo e socialismo sob a ótica do líder cubano, primeiro chefe que, notadamente, se professou materialista ateu. Neste, o autor procurou dar voz para que Fidel explicasse suas visões e por que um país, onde a maioria do povo era religioso, o partido que comandava proibiu a adesão de membros confessadamente religiosos ao partido.

A figura de Fidel no pós-1959 foi construída para integrar o panteão dos heróis latino-americanos. Eric Hobsbawm nos aponta para esse dado de forma instigante, posto que o próprio historiador não se isenta de relatar sua admiração pessoal às ideias e discursos de Castro. Ouvir os discursos do líder é, para Hobsbawm (2006, p. 426), ter acesso às memórias de atmosfera inebriantes: "uma vez na vida, a revolução foi sentida como uma lua de mel coletiva”.

Neste sentido, em que medida o livro "Fidel e a religião" resultou da representatividade da figura de Fidel Castro no imaginário coletivo da esquerda latino-americana pós-1959?

A obra é composta de um prefácio onde Frei Betto relata os "Caminhos de um encontro", em duas partes. A edição original é de 1985. O ambiente religioso, na maior parte do livro, é tratado a partir da trajetória de vida do líder cubano. Posterior ao primeiro encontro de Frei Betto com Fidel, durante o primeiro aniversário da Revolução Sandinista, o editor Caio Graco Prado, em conversa com Frei Betto, propôs que ele entrevistasse Fidel Castro sobre as questões religiosas e transformasse o material em livro. O processo que vai dar origem ao livro é complexo, pois, da primeira visita a $\mathrm{Cu}-$ ba até o momento em que a entrevista se concretizou, Betto retornou 12 vezes à ilha. Encaminhou o projeto ao dirigente cubano, que só o respondeu em fevereiro de 1985, quando Betto foi jurado do prêmio literário da Casa de las Americas; ocasião em que pôde materializar seu projeto.

No livro, Frei Betto entrevistou o líder cubano com enfoque na relação entre o sistema socialista Cubano e os cristãos naquele país, sendo que 
no próximo livro, “O paraíso perdido”, procurou fazer uma análise macro sobre a vida dos cristãos em todos os países socialista reais, cujo projeto foi realizado entre 1979 e 1990.

"O paraíso perdido: nos bastidores do socialismo" foi resultado dos relatos de viagem de Frei Betto aos países socialistas, entre 1979 e 1990. Os textos vão do ensaio à crônica, onde o autor buscou compreender a vida cotidiana dos cristãos naqueles países. Os 33 capítulos têm sempre em seus títulos temas ligados à culinária dos países retratados. Outro aspecto importante da obra é o simbolismo enquanto livro publicado aos 50 anos de vida do autor, que se inspirou em Graciliano Ramos para se autorretratar no momento. A capa da obra é outro aspecto interessante, pois traz representados os líderes e figuras marcantes dos países socialistas, além de Marx e Engels. Através da obra é possível ver refletidos não só fatos da história dos países visitados por Frei Betto, como sua relação com os fatos da História do Brasil.

A edição original saiu pela Geração Editorial, fundada pelo jornalista Luiz Fernando Emediato3, em 1992, durante a bienal do livro de São Paulo. De acordo com Marcelo Timotheo da Costa (2012, p. 285-286), em "Epístola à Teófilo", "O Paraíso perdido" é parte de variadas análises críticas das experiências socialistas históricas, ocorridas no decorrer da década de 1990 e influenciadas pela queda do Muro de Berlim, no segundo semestre de 1989. Algumas análises anunciavam e celebravam a derrota dos ideários de esquerda, outras, procuravam entender o porquê essa experiência se esfacelou. Frei Betto adotou essa segunda postura, inventariando a partir de sua vivência pessoal, construída por múltiplas visitas aos países socialistas.

Um aspecto marcante de "O paraíso perdido: nos bastidores do socialismo”, apontado por Marcelo Timotheo (COSTA, 2012, p. 292-293), é a sua noção de intimidade, expressa pelo subtítulo da obra. Característico da prosa cristã, em especial da escrita biográfica cristã, Frei Betto representou al-

\footnotetext{
3 Mineiro, trabalhou na filial do Jornal do Brasil, em Minas, no jornal O Estado de São Paulo, e foi diretor de jornalismo do Sistema Brasileiro de Televisão (SBT). Entre 2007 e 2009 foi presidente do conselho deliberativo do Fundo de Amparo ao Trabalhador, representando a força sindical.
} 
guém que vivenciou o cotidiano dessas sociedades para além da forma turística.

Em 2015, Frei Betto e a Editora Rocco ofereceram uma nova reedição de "O paraíso perdido: viagens ao mundo socialista". O recorte temporal da nova edição situa-se entre 1979 e 2012. Os títulos dos capítulos foram renomeados: eles agora possuem o nome do local e o evento sobre o qual fala, por exemplo, "Havana: Dom Pedro Casaldáliga encontra Fidel”. Nessa edição, os capítulos após a queda do Muro de Berlim e da derrota da Frente de Libertação Nacional - fim da Revolução Sandinista, trataram especificamente de Cuba. O livro é todo vermelho e a arte gráfica bem mais sóbria que a versão original, com qual trabalhamos. O livro permaneceu dedicado a Paulo Vannuchi, contudo, ele tece agradecimento a Thomaz Ferreira Jensen4, pelas sugestões à nova edição.

Em “Detestáveis e apimentados tacos”, Frei Betto relata a sua viagem rumo à Conferência Episcopal de Puebla e seu encontro com Hugo Assmann, na Costa Rica. Os dois se conheceram quando Assmann ocupava o cargo de assistente eclesiástico da JUC e da Ação Católica, em Porto Alegre, no início de 1960, e Betto dirigente da JEC. Com advento do golpe de 1964, Assmann exila-se no Chile e, posteriormente, casa-se.

Frei Betto também conta sobre o contato que realizou com os Sandinistas, no início de 1979, em San José, que, segundo ele, foi a principal base dos jovens que arquitetaram a derrubada da Família Somoza, após uma década refugiados. Conhece o comande José Antonio Sanjinez, formado pela Universidade Gregoriana de Roma, que trocou a Companhia de Jesus pela Frente Sandinista de Libertação Nacional, e o comandante Eden Pastora, que abandonou a revolução em seu início. Nesse quadro, Betto questiona como conciliar a violência do processo revolucionário com a fé cristã. Outro momento marcante foi o encontro, ciceroneado por Assmann, entre Betto e Ernesto Cardenal.

Finalmente, Frei Betto desembarcou na cidade do México, onde se uniu a outros teólogos da libertação para participar da conferência, que, di-

\footnotetext{
4 Thomas Ferreira Jansen foi assessor técnico do Departamento Intersindical de Estáticas e Estudos Socioeconômicos (DIEESE), e publicou "Desafios do mundo do trabalho" pela Editora CEPIS. É formado em Economia pela Universidade de São Paulo (USP).
} 
ferentemente da anterior, não contou com auxílio de qualquer teólogo progressista. A repercussão do conflito nicaraguense foi recebida de forma indigesta, pois os bispos sofreram pressão para manifestar apoio aos sandinistas e cederam à pressão. Entretanto, o Vaticano manteve total silêncio sobre o processo revolucionário.

“Ao lado da casa da mulher que vende pães” é um relato da primeira passagem de Frei Betto pela Nicarágua, em setembro de 1979, intermediada por Uriel Molina, franciscano e diretor do Centro Antônio Valdivieso, em homenagem a um bispo do país e assassinado em 1950 por defender os direitos dos indígenas. As missas de Molina transformaram sua paroquia em um centro de propaganda sandinista, atraindo muitos turistas ideológicos interessados em presenciar o casamento da fé cristã com a revolução, e televisões da Europa e dos Estados Unidos. A bandeira sandinista ficou no altar. A capital Managua se encontrava desolada pela pobreza e pelo terremoto, que a deixou suja e em ruínas.

O sentimento expressado por Frei Betto (1993, p. 26) demonstra muito deste esforço conciliatório e nos mostra como ele conferiu sentido à memória cristã a partir da noção de luta pela liberdade. É neste sentido que Frei Betto evoca um poderoso paralelo entre Revolução Sandinista e a fuga do Egito pelos hebreus. Os processos de dominação misturam religião e geopolítica, de modo que os Estados Unidos da América passam a ser vistos por uma ótica tanto religiosa quanto política: a revolução é sentida como libertação do povo de seu algoz.

O autor traçou um perfil histórico e panorâmico do país, buscando as raízes do movimento sandinista que possuiu este nome em homenagem Augusto César Sandino, herói do país, morto nos anos 1930 a mando de um dos membros da família Somoza. Foi com apoio dos EUA que essa família controlou a Nicarágua por três gerações, até ser derrubada pelos revolucionários. Outro episódio narrado por Frei Betto foi a sua participação, juntamente com Lula e Hugo Assmann, nas comemorações do primeiro aniversário da revolução sandinista, em 1980. Naquele momento, o político brasileiro se encontrou com os representantes locais: "improvisa-se uma sessão de doutrinação política” (BETTO, 1993, p. 30). O velho comunista apressa- 
se em plantar na cabeça do jovem sindicalista os conceitos lapidares da "ciência da história"

Na Nicarágua sandinista, Frei Betto e os demais visitantes foram acomodados em luxuoso hotel da época da ditadura dos Somoza, antiga residência de milionários norte-americanos, amigos do ditador deposto. $\mathrm{O}$ local foi expropriado com a revolução, e naquele momento serviu para hospedar todos os seus convidados para a comemoração do primeiro aniversário. O hotel deixou expostos os problemas de uma revolução que destruiu todo aparato estatal e teve que se virar com o que estava disponível. O Country Clube de Manágua também foi desapropriado pela Revolução Sandinista, tendo sido palco da festa, onde Fidel Castro era a grande estrela da comemoração da manhã seguinte, na Praça 19 de Julho, onde estavam expostas as imagens de Augusto César Sandino e de Carlos Fonseca Amador, fundador da Frente Sandinista de Libertação Nacional, de 1961. Além das bandeiras da Nicarágua e da FSLN, segundo Frei Betto (1993, p. 31):

Destacam-se no palanque oficial Fidel Castro, os nove comandantes da Direção Nacional da Frente Sandinista e Maurice Bishop, que em março deste ano liderou a libertação de Granada. (Em 1983, os EUA invadiriam Granada e assassinariam Bishop)5.

Fidel deixou a população de Manágua, cerca de quase 600 mil pessoas, em completo silêncio. O modelo e o líder eram altamente apreciados por Frei Betto, destacados no filme El Brigadista (1977), onde se pode observar um pouco da educação cubana. Já em relação à Revolução Sandinista, Betto destaca a desconfiança que ainda provoca entre os empresários nicaraguenses e as delegações ocidentais, pois se esperava a implantação de um regime liberal após a queda de Somoza.

"Ritmos de maracas e sabor de rum" continua a tratar das revoluções latino-americanas, cubana e sandinista, sobrelevando as resistências promovidas pelo imperialismo, especialmente ao governo dos EUA. Continua explicando como essas ações refletiram no continente, com a eclosão das ditaduras militares e especialmente no Brasil, onde diversos setores da sociedade foram influenciados pela propaganda estadunidense, apoiando o

5 O país caribenho de Granada foi dirigido por Bishop de 1979 a 1983. 
golpe. Do outro lado, o primeiro movimento cubano e depois o nicaraguense influenciaram as resistências contra os regimes ditatoriais, principalmente o brasileiro. Uma situação exemplar desta lógica foi a reunião na casa do vice-presidente da Nicarágua, Sérgio Ramirez, onde se faziam presentes figuras que permeavam o imaginário latino-americano da segunda metade do século XX, como Miguel D’Escoto, padre e ministro Nicaraguense, Manuel Piñeiro, responsável pelas relações do Partido Comunista Cubano com a América Latina, José Miyar Barrueco, conhecido por Chomy Miyar, secretário particular e chefe da segurança de Fidel, e Marta Harnecker, esposa de Piñeiro e autora de "Conceitos elementares do materialismo histórico, além de Lula e Fidel”. As discussões giraram em torno das contradições históricas entre os diversos grupos sociais e políticos da região, em especial os de Cuba e da Nicarágua, visando compreender como eles reagiram aos processos revolucionários.

De acordo com Frei Betto (1993, p. 44), a estratégia do governo sandinista tinha como objetivo dar base à população para discutir e construir o melhor percurso ao desenvolvimento das forças produtivas. Isso envolvia uma frente de planejamento agrícola visando dirimir a dependência da economia externa e um projeto educacional, que se mostrou muito exitoso, sob a justificativa de que era a partir da educação que a população teria condições de participar ativamente da construção do novo código social que se pretendia delinear.

O diálogo entre cristãos e revolucionários sandinistas foi valorizado em tom crítico na ótica de certos setores da esquerda. Segundo Betto, no Brasil a esquerda tem a cabeça maior do que o coração, especialmente no trajeto feito em companhia da comandante Monica Boltodano, que já havia visitado o Brasil no ano anterior, em 1980. E de Marisa Marega, autora de "Nicarágua Sandinista".

"Os comunistas comem camarões" relata a viagem de Betto a Cuba, devido a sua participação no Prêmio da Casa das Américas, que ocorreu concomitante ao Encontro de Intelectuais pela Soberania de nossa América, idealizado anteriormente por Gabriel García Márques. O itinerário feito em companhia de boa parte da esquerda brasileira: Jaguar (cartunista), Ruth Escobar, Leandro Konder, Argemiro Ferreira, Mário Schemberg, Fernando 
Morais e Ricardo Kotscho, dentre outros, além dos sectários do MR-8, que questionaram o que os papas hóstias iam fazer em Cuba. Betto e Kotscho se conheceram durante as greves dos metalúrgicos do ABC. A diversidade e as posturas dessas figuras representaram perigo iminente de conflito. De acordo com Frei Betto (1993, p. 52), quando a esquerda se reunia, não havia surpresas, pois pareciam reuniões da direita, onde as ideias se transformavam em propósitos cruéis.

Em suas andanças por Havana, Betto analisou o resultado da revolução por meio da vida cotidiana da gente comum, ressaltando as benesses e os problemas, especialmente aqueles causados pelo embargo dos EUA. Intercalando com os compromissos do evento, a exemplo do jantar no Palácio da Revolução, onde o anfitrião foi o ministro da Cultura Cubano, Armando Hart, se destacaram as figuras dos poetas e escritores de língua hispânica, como Luis Cardoza Y Aragón, Ernesto Cardenal e Corenel Urtrecho, Roberto Retamar e o vice-presidente da Casa das Américas.

Os conflitos gerados pela ideia de uma incompatibilidade entre cristãos e marxistas na vida prática ficaram bem marcados nessa viagem a $\mathrm{Cu}$ ba. Tanto nos conflitos entre os convidados do evento, como nas dificuldades do diálogo dos cristãos cubanos para com o Estado. Durante o evento, em que Fidel foi o anfitrião, este incube Frei Betto de fazer em Cuba o mesmo trabalho de promoção do diálogo entre cristãos e marxistas, já realizado por ele na Nicarágua.

Em "Rum com soda", Frei Betto estava de volta à Nicarágua e reunido com os padres Miguel D’Escoto6, Gustavo Gutiérrez e outros padres da América Latina, bem como membros leigos do governo sandinista. Ocorre-

\footnotetext{
${ }^{6}$ Miguel D’Escoto nasceu nos EUA em 1933, filho de diplomata nicaraguense, foi ordenado sacerdote 1961. Tornou-se oficial do Conselho Mundial de Igrejas, criou em 1973 a Fundação Nicaraguense para o desenvolvimento Integral Comunitário, e, após a vitória da Revolução Nicaraguense, foi nomeado Ministro da Relações Exteriores do Governo Sandinista (cargo que exerce 1979 a 1990). Por ocupar cargo no governo, foi suspenso em 1985, junto com Ernesto e Fernando Cardenal, pelo Papa João Paulo II. Entre 2008 e 2009 presidiu a $63^{\text {a }}$ Assembleia Geral das Nações Unidas. A suspenção de D’Escoto foi revogada pelo Papa Francisco em 2014. Para mais informações, consultar: www.ihu.unisinos.br/noticias/53.3916-vaticano-revoga-suspensao-contra-o-padremiguel-descoto e www.un.org/ga/president/63. Acesso em: 19 jan. 2016.
} 
ram questionamentos sobre a participação de sacerdotes no governo sandinista, principal tema do debate e dos trajetos de Frei Betto.

Em "Vovó toma calmamente sua coke", Frei Betto (1993, p. 73) tratou especificamente do seu trabalho de assessoria aos religiosos cubanos: "Entrego a monsenhor Jaime Ortega, recém-nomeado arcebispo de Havana, uma carta de congratulações de Dom Paulo Arns. Ele manifestou desejo de convidar-me para uma reunião com a conferência episcopal”.

Já em "Mergulhado no caldeirão", Frei Betto refletiu sobre o papel social da Igreja na América Latina, analisando especificamente o caso Nicaraguense após a revolução sandinista, sendo que seus líderes religiosos católicos, como Ernesto Cardenal, foram publicamente repreendidos por João Paulo II durante sua viagem a Nicarágua, em março de 1983: Betto (1993, p. 83) narra como esse embate simbolizava, no interior da Igreja, uma disputa por sentidos sem que se questionasse a existência e o papel evangelizador da igreja, mas a própria forma de se conceber essa relação.

A postura "belicosa" adotada pelo Papa João Paulo II, durante sua estadia na Nicarágua em março de 1983, foi duramente criticada por Frei Betto. O Papa não beijou o chão, nem abraçou as crianças, atitudes que adotava em visita a outros países. João Paulo II "cumprimentou friamente as autoridades locais e fez uma advertência pública ao sacerdote e ministro da Ernesto Cadernal" (BETTO, 1993, p. 84).

Esta repreensão foi marcante na história do catolicismo latinoamericano, por ser um dos sinais representativos da repressão do Vaticano ao Catolicismo Progressista e à Teologia da Libertação. Em entrevista ao Instituto Humanitas Unisinos7, em outubro de 2009, Cadernal afirmou que João Paulo II o humilhou. O papa exigia que Cadernal deixasse seu cargo no governo sandinista. Além disso, em seus discursos, não falou em paz ou fez oração pela paz, tampouco pelas vítimas da reação financiada pelos EUA: "Quando a multidão clamou que o fizesse, encarou-a com severidade e exigiu contrariado 'Silêncio'! Tratava-se antes fortalecer a Igreja e a auto-

\footnotetext{
7 Entrevista de Ernesto Cardenal disponível em www.ihu.unisinos.br/noticias/noticiasarquivadas/26706-\%60\%60joao-paulo-ii-me-humilhou\%60\%60-entrevista-comernesto-cardenal. Acesso em: 13 jan. 2016.
} 
ridade episcopal para deter o risco de a Nicarágua caminhar para o comunismo" (BETTO, 1993, p. 85).

De acordo com Frei Betto, durante o domínio espanhol e samozista, a Nicarágua foi ocupada e monitorada pela religiosidade da Igreja Católica, a exceção da costa atlântica, cujo sincretismo fundia raízes indígenas, tradições católicas e influência protestante. Já com a revolução sob controle dos meios de comunicação e dos movimentos sociais, ruíram por terra as colunas de poder dos universos anteriores. Um novo sentido ganhou espaço produzido pela inspiração nacionalista de Sandino, pelo marxismo e pela teologia da libertação, ameaçando o monopólio religioso do episcopado e o seu setor conservador resistente.

De acordo com Kenneth Serbin (2008, p. 282), na década de 1980, o experimentalismo e o ativismo pós-Vaticano II perdeu espaço para a ortodoxia pré-conciliar e o espiritualismo decorre da chamada reação neoconservadora no catolicismo latino-americano. No pontificado de João Paulo II (1978-2005), o Vaticano e os bispos conservadores revogaram as inovações, permitidas pelo Concílio e restringiu a atividade política do clero. Antimarxista ferrenho, João Paulo II ajudou a derrubar o comunismo soviético e a amordaçar a Igreja Progressista Latino-Americana.

A reação neoconservadora na América se fez visível para além do âmbito da Igreja. Frei Betto relata as diversas tentativas para derrubar a revolução Sandinista e acabar com os seus feitos. Milhares de vidas inocentes foram ceifadas pelos mercenários partidários de Samoza. Tais tentativas foram patrocinadas pelos EUA e ignorada pelo episcopado do país.

Nos capítulos "Pernil assado com farofa", "Quanto custa uma garrafa de flor de Canã", "Peixe cru com cebola e limão" e "Entre mojitos e daiquiris”, Frei Betto relata suas viagens entre Cuba e Nicarágua e à Lima, no Peru, terra de Gustavo Gutierrez, que recebeu visita do Papa João Paulo II, em janeiro de 1985 .

Em “Do Camarão a religião" e "Ovos de tartaruga”, Frei Betto discorre sobre o processo de publicação do livro Fidel e a Religião, o encontro entre Fidel e 63 intelectuais brasileiros para o Encontro sobre a Dívida Externa na América Latina e no Caribe. A troca de correspondência entre o líder cu- 
bano e o Cardeal Dom Paulo Evaristo Arns foi intermediado por Frei Betto, assim como a Visita de Dom Pedro Casaldáliga à Nicarágua e Cuba ${ }^{8}$.

Frei Betto, acompanhado dos irmãos Clodovis Boff e Leonardo Boff, convidaram Dom Pedro Casaldáliga ${ }^{9}$, que planejava visitar a Nicarágua, para que também fosse a Cuba. Em 11 de setembro de 1985, o bispo foi recebido pelos religiosos. Dialogaram sobre a importância da religião para o processo revolucionário na América Latina. Após discursar na abertura do Diálogo Juvenil e Estudantil sobre a Dívida Externa, Dom Pedro Casaldáliga, os irmãos Boff e Frei Betto partiram para a Nicarágua, onde participaram da Jornada de Oração pela Paz, coordenada pelo Padre Miguel D'Escoto. No período concomitante à visita dos religiosos brasileiros, a Nicarágua foi bombardeada e invadida por cerca de 800 mercenários vindos de Honduras. Entretanto, as tentativas de negociação do presidente Nicaraguense, Daniel Ortega, não foram recusadas pelo governo hondurenho: "À tarde, na Universidade Centro-Americana, dirigida pelos jesuítas, Dom Pedro Casaldáliga, Adolfo Pérez Esquivel, Prêmio Nobel da Paz, o jesuíta Luiz Pérez Aguirre e eu demos entrevista à imprensa, reforçando o apelo de Daniel Ortega" (BETTO, 1993, p. 1967).

Em novembro de 1985, Frei Betto, em companhia de Hélio Pellegrino e Emir Sader, retornou a Cuba para o $2^{\circ}$ Encontro de Intelectuais pela Soberania do Povos e para o lançamento de "Fidel e a religião". Do encontro de intelectuais, participam também Gabriel García Márquez, Nélida Pinõn, Ernesto Cardenal, Adélia Prado, Chico Buarque, Padre José Oscar Beozzo, Antônio Candido, Carlos Guilherme Mota, Eduardo Galeano, Ítala Nandi, Marlene França, Roberto D’Ávila, entre outros (BETTO, 1993, p. 168-180).

8 Impossibilitado de ir ao evento, o Cardeal e Arcebispo de São Paulo, Dom. Paulo Evaristo Arns, manda uma carta a Fidel Castro e demais participantes contendo votos de estima e clamando pela "bem-aventurança da fome e da sede de justiça, a fim de sermos sempre fieis às aspirações, libertadores de nossos povos” (BETTO, 1993, p. 158). Após essa carta de Dom Paulo, Fidel concedeu uma audiência exclusiva para a uma delegação de bispos cubanos que foram aos EUA retribuir a visita que fizeram a Cuba, em janeiro de 1985 .

9 Dom Pedro Casaldáliga produziu um diário de viagem sobre a visita a Nicarágua Sandinista, e publica sob o título de "Nicarágua: combate e profecia", pela editora Vozes. A viagem de Casaldáliga é analisada por Samuel Vilaça Martins. Ver: MARTINS, S, V. Trajetória e Memória: A viagem de Dom Pedro Casadáliga à Nicarágua sandinista. Dissertação (Mestrado em História), Universidade Salgado de Oliveira, Niterói, 2012. 
Fidel, por intermédio da intelectualidade presente, concedeu a primeira entrevista a uma TV brasileira após 1964, feita por Roberto D’Ávila, na época da Rede Manchete ${ }^{10}$.

Frei Betto e Hélio Pellegrino se aproximaram nos anos 1970, quando este tratava psicologicamente dos perseguidos e torturados políticos da ditadura, entre eles Frei Fernando de Brito (preso com Frei Betto), como já dito anteriormente. De acordo com Kenneth Serbin (2008, p. 238), Hélio Pellegrino era "católico devoto que acreditava fervorosamente na ideia de ressureição, ele insistia na ligação entre religião e psicanalise e era adepto da Teologia da Libertação".

Para esses intelectuais, Cuba constitui-se como um lugar onde a intelectualidade latino-americana pode dialogar e refletir durante esse período final de vigência das ditaduras, especialmente no que tange aos assuntos e figuras reprimidos pelas ditaduras do continente latino-americano: na ocasião, Frei Betto (1993, p. 174) não deixa de externar sua emoção em rever Frei Tito. Ao falar do papel da revolução cubana nas mentes da esquerda ocidental latino-americanas, Eric Hobsbawm (2006, p. 427) constrói Cuba como "cenário ideal" para um entusiasmo prospectivo das revoluções. Este cenário mostrou-se extremamente profícuo para os debates relatados por Frei Betto ${ }^{11}$.

Os países do socialismo real na Europa e na Ásia foi o enfoque de Frei Betto nos capítulos a seguir, que continuam a ser intercalados com Cuba: "Café, chá ou Coca-Cola" trata da primeira incursão de Frei Betto pelos países socialistas europeus e Varsóvia, em janeiro de 1986, quando participou do Congresso de Intelectuais pelo Futuro Pacífico do Mundo, ou Congresso da Paz. Este evento pretendia reprisar o congresso de 1948, após Segunda Guerra Mundial. Para Frei Betto, tudo parecia meio Chapa Branca.

\footnotetext{
10 A entrevista de D’Ávila a Fidel está disponível em www.youtube.com/watch? $\mathrm{v}=\mathrm{MpL}$ yTB2XhI. Acesso em: 16 jan. 2016. O filme "Frei Tito" recebeu o prêmio Margarida de Prata da Conferência Nacional dos Bispos do Brasil (CNBB), em 1984.

${ }^{11}$ A intelectualidade brasileira e latino-americana nutriu, e alguns ainda nutrem, uma grande admiração pela revolução Cubana e seus resultados na educação e saúde, apesar do embargo econômico e do isolamento após o fim do socialismo real Europeu. “[...] Hélio Pellegrino, com os olhos brilhantes, lavou o rosto no banheiro apertado e mostrou-se esfuziante com a perspectiva de conhecer Cuba" (BETTO, 1993, p. 169).
} 
Frei Betto descreveu também o cotidiano da Polônia, classificando-a como uma vida altamente regrada. Havia pouca variedade na alimentação, uma vez que o Estado controlava todos os espaços. O anticomunismo, a rejeição aos russos e alemães eram fortes. O povo, muito católico, estampava as imagens do Papa João Paulo II por todos os cantos. O sentimento anticomunista e a crise econômica dos anos 1970 deram força aos protestos de Lech Walesa (BETTO, 1993, p. 181-184). Ao falar no Congresso, Frei Betto frisou que o Brasil era o sexto produtor mundial de $\operatorname{armas}^{12}$, mas que a pior guerra era contra a fome, especialmente aquela causada pela dívida externa da qual o Brasil e a América Latina se encontravam submetidos. Assim, a humanidade não deveria ser dividida por binômios branco-negro, desenvolvidos-subdesenvolvidos, comunistas-cristãos, mas entre aqueles que lutavam pela vida e os que lutavam só pelas próprias vidas. A paz deveria ser fruto da justiça e não apenas de um equilíbrio de forças, uma vez que se desejamos a paz, deve-se acabar com a injustiça social (BETTO, 1993, p. 183).

As viagens de brasileiros à União Soviética foram inúmeras e deixaram diversos relatos ainda pouco explorados pela historiografia, de acordo com Edvaldo Correa Sotana, em "Relatos de viagens à URSS em tempos de Guerra Fria: uma prática de militantes comunista brasileiros”. Os relatos de experiências desses brasileiros objetivaram aprender sobre o sistema político soviético, construindo práticas discursivas e representações sobre a URSS. As temáticas variadas, tratadas nesses relatos de viagem, são amplas e os escritores descrevem os itinerários de viagem, a vida do povo soviético e o regime implantado.

Após 1964, muitos comunistas deixavam o Brasil para buscar exílio na União Soviética. A partir disso, as viagens ganharam uma outra configuração. O clima repressivo não contribuía para a produção e difusão dos relatos de viagem e, a partir de 1960, Cuba e China começaram a figurar enquanto experiências socialistas que atraíam interesse de parcelas significativas.

${ }^{12}$ Segundo estimativas, atualmente o Brasil é o quarto exportador de armas ficando atrás apenas de EUA, Alemanha e Itália. Mais informações em: http://noticias.uol.com. br/internacional/ultimas-noticias/2013/07/08/brasil-e-o-4-maior-exportador-dearmas-do-mundo.htm. Acesso em 23 jan. 2016. 
De acordo com Frei Betto (1993, p. 192-193), "eu era o único represente de toda a América Latina, o que me constrange por constatar o quanto o nosso continente é irrelevante para eles". No evento, proferiu "Princípios comuns para uma ordem moral de paz com Justiça”, sobre os religiosos com quem dialogou na ocasião, Betto mostra como o contraste entre a experiência do diálogo direto com a imagem produzida pelos discursos midiáticos trouxe uma dimensão mais crítica à postura dele próprio quanto à relação entre religiosos e o regime soviético. Emblema desta reavaliação foi sua conversa com o chefe dos rabinos na URSS (BETTO, 1993, p. 193).

Encerrado o evento com apelos de paz a Reagan e a Gorbachev, Frei Betto continuou na Rússia. Foi convidado a se reunir com o presidente do conselho para assuntos religiosos da União Soviética, Konstantin Khartchev. O padre da igreja ortodoxa Alexander Ziliayev tentou acompanhar Frei Betto, mas foi impedido. Khartachev e Frei Betto falaram sobre o livro "Fidel e a religião". Sobre a relação religião e Estado, havia oficialmente 69 denominações religiosas reconhecidas nas 15 repúblicas soviéticas, nas quais havia proibição do ensino de catequese ou de ateísmo aos menores de 18 anos, pois a maioria dos frequentadores dos locais de culto eram maiores de 50 anos. Nesse evento foram tratados o papel da Igreja na América Latina e na Polônia. Ainda se falou da questão mulçumana alçada pela guerra do Vietnã e a visão da questão religiosa exposta pelos manuais soviéticos exportados para a América Latina. Para Frei Betto, frente à religião, havia três escolhas: perseguir, marginalizar ou coexistir. E as duas primeiras opções gerava um desgaste grande perante povos religiosos, como os latino-americanos.

Em "Brindes com vodca” e "As melhores receitas da antiga Rússia”, Frei Betto retornou à URSS em junho de 1987, convidado pela Igreja Ortodoxa Russa e pelo Conselho de Assuntos Religiosos. Mas, dessa vez, estava acompanhado dos teólogos Leonardo e Clodovis Boff, do sociólogo Pedro Ribeiro de Oliveira, e do pastor Jether Ramalho. Eles visitam Moscou, Leningrado (São Petersburgo) e Riga (Letônia), no intuito de conhecer como o socialismo soviético na sua prática, com os seus problemas e contradições para além dos estereótipos capitalistas-ocidentais, se relaciona com a Igreja Ortodoxa Russa. 
No diálogo entre os teólogos brasileiros e os teólogos da Igreja ortodoxa Russa, procurou-se classificar a Teologia da Libertação enquanto produto de um povo cristão, marginalizado e oprimido, que tentou romper com essa sociedade para construir uma nova, mais integradora e socialmente igualitária. Para Frei Betto (1993, p. 238), os teólogos ortodoxos não pareciam entender ou absorver o que falavam os teólogos da libertação, visto adotar uma teologia fixa que consentia o socialismo como uma fatalidade, desconhecendo a realidade latino-americana. Por isso receavam que a Teologia da Libertação criasse uma dissidência na Igreja Romana.

Os relatos dessa viagem, na edição original de "O paraíso perdido" e "Nos bastidores do socialismo", deu muita ênfase aos debates teológicos travados entre os teólogos da libertação e os teólogos russos, com ênfase na hierarquização (autoritarismo) presente na sociedade russa. Porém, a reflexão mais profícua sobre o papel político dessa viagem está nas duas primeiras páginas do capítulo "Leningrado: o que é Teologia da Libertação", da nova edição de "O paraíso perdido: viagens ao mundo socialista" 13.

Os teólogos brasileiros debateram, no trem que os levou a Leningrado, qual estratégia deveria ser usada na Letônia e Lituânia, países que possuem um número significativo de católicos. De acordo com Frei Betto, ao chegar a esses lugares, eles sabiam que encontrariam católicos conservadores que acreditavam que a Teologia da Libertação era o cavalo de Tróia do marxismo na Igreja. Essa foi a primeira vez que visitantes cristãos entravam oficialmente naqueles países anexados pela Rússia, na URRS. Parece até que o Kremlin pressentia que o socialismo soviético estava mal e, quem sabe, o grupo de teólogos latino americanos poderiam salvar naquelas nações impregnadas de fé cristã, diz sarcasticamente Frei Betto. Enfatizou ainda que precisavam deixar claro que não foi o que eles imaginam. Já, para Clodovis Boff, deveria-se enfatizar que eram eclesiásticos (BETTO, 2015, p. 237).

13 Os dois livros narram os mesmos episódios. Na maioria das vezes a edição original é mais detalhista em seus relatos. Acredito que isso se deve à extensão do recorte temporal da segunda edição, que vem até 2012, falando especialmente de Cuba. Contudo, este diálogo entre os teólogos brasileiros, especificamente, não aparece na primeira edição. 
Frei Betto acreditava que a recepção e interpretação dos letões e lituanos repercutiria em Roma, visto que nenhum obstáculo havia ocorrido até momento ao trabalho nos países socialistas. O problema não era a sua liberdade ou mobilidade pessoal e sim a possibilidade da construção de um cristão assumir suas convicções socialista sem ter que fazer uma única opção (BETTO, 2015, p. 237-238): “ora, não sei se vamos mudar a cabeça dos católicos, mas quero mexer com a dos comunistas"14.

Em outubro de 1987, Frei Betto retornou a Varsóvia, a convite da Associação Social Cristã, ocasião em que os frades dominicanos se negaram a hospedá-lo, ao que Frei Betto justifica pelo sentimento antipolítico com relação à esquerda. Em 16 de outubro, incentivado por cristãos que almejam o diálogo entre Igreja e Estado, Frei Betto foi entrevistado, ao vivo, por um dos mais importantes telejornais da Polônia. Foi destaque, porque raras vezes, em décadas, a TV entrevistava um religioso que via o socialismo como ele. Foi também recebido na Universidade Católica de Lublin, onde Karol Woytila (Papa João Paulo II) foi professor de ética. Ao ir à missa de domingo no convento dominicano, em 18 de outubro, recebeu, no almoço, indiretas e diretas provenientes do anticomunismo arraigado na Igreja.

A intenção de Frei Betto de falar com Lech Walesa deixou seus anfitriões incomodados, tentando demovê-lo dessa intenção, mas Frei Betto conseguiu a posteriori o telefone da casa de Walesa, com um jornalista, e entrou em contato com o próprio Walesa que o atendeu. Ele havia lido "Fidel e a religião". Através do seu intérprete, conseguiu marcar a entrevista para daí dois dias.

O encontro entre Frei Betto e Lech Walesa foi, certamente, o episódio mais conflituoso do livro, como bem demonstra o título "Almoço indigesto com Lech Walesa”. Frei Betto, acompanhado por seus dois interpretes, e Walesa se encontram na casa paroquial da igreja Santa Brígida. O capelão

\footnotetext{
$14 \mathrm{O}$ fato de Frei Betto não receber publicamente qualquer advertência ou sanção doutrinal da hierarquia da Igreja deve-se a ele nunca ter ocupado cargos elevados dentro da hierarquia, diferentemente de seus companheiros de viagem, o bispo Dom Pedro Casaldáliga que fora censurado por sua viagem a Nicarágua apoiando os revolucionários sandinistas, e do ex-frade franciscano Leonardo Boff, professor de Instituto Teológico Franciscano de Petrópolis e editor das revistas Concilium, Cultura Vozes e Revista Eclesiástica Brasileira (REB), instrumentos de formação e divulgação de ideais católicos.
} 
de solidariedade, padre Radca Jankoski, e os outros assessores do sindicato acompanhavam Walesa. Os dois discutiram sobre diversos assuntos, o livro "Fidel e a religião", mas também a entrevista de Frei Betto à TV polonesa e a militância política deste enquanto membro da Igreja. Walesa defendeu que religião e política deveriam andar separados, assim como outros temas: a relação entre Teologia da Libertação e o marxismo, a recente fundação do PT, Lula e seu mandato como deputado federal constituinte. Estes fatos foram vistos como fatores negativos por Lech Walesa e seus companheiros. Já Frei Betto incomodou-se com a postura impositiva de Walesa e com a ostentação do padre e da sala onde ocorreu o almoço, pois Frei Betto já havia almoçado anteriormente no hotel em que se hospedara.

Walesa afirmou que a Teologia da Libertação estava influenciada pelo marxismo e pelo socialismo, representando uma traição a igreja e a sua unidade, mantida por uma postura de equilíbrio da igreja: "que estende a mão ao mendigo e ao rei sem estar ao lado de nenhum dos dois” (BETTO, 1993, p. 264-265). Frei Betto, por outro lado, afirmou não ser marxista e que na América Latina todos que lutavam por justiça eram considerados comunistas, por não aceitarem a opressão.

O clima de tensão permeou toda a conversa, tanto que Walesa disse que, se vivesse no Brasil, também lutaria para mudar a situação do país, mas não atiraria com a cruz. Já Frei Betto garantiu que não queriam disparar, mas sim esgotar todos os meios pacíficos, uma vez que ninguém na igreja desejava a violência. Na América Latina, sacerdotes foram assassinados por problemas fundiários: "o grande problema do Brasil é que existem fazendas do tamanho da Holanda e a reforma agrária é o principal tema da conferência episcopal" (BETTO, 1993, p. 265).

Walesa questionou se Frei Betto pretendeu escrever um livro, como fez com Fidel, em suas 23 horas de conversa, porque eles não falaram 23 horas, Frei Betto disse que não teria tempo, pois estava retornando ao Brasil no dia seguinte.

Nos próximos capítulos, Frei Betto relata que viajou a URSS e a Alemanha, e acompanhou a queda do muro de Berlim e os impactos da desintegração do socialismo real no Leste Europeu. Foi à China acompanhado dos irmãos Boff e observando a vida dos cristãos no socialismo chinês, re- 
fletindo o processo que levou à derrota do sandinista nas urnas na Nicarágua e a dificuldades e isolamento de Cuba nesse processo de desintegração do socialismo real.

Em "Hélio Pellegrino, auxiliar de cozinha", refletiu sobre seu falecimento, em março de 1988, período que Frei Betto estava em Cuba, onde realizou trabalho pastoral e acompanhou uma comitiva de integrantes do PT ao país. Na sua viagem à Berlim Oriental, em de fevereiro de 1988, participou do Seminário sobre Teologia no Terceiro Mundo, promovida pela Faculdade de Teologia da Universidade de Humboldt-Berlim, em memória do teólogo luterano Dietrich Bonhoeffer, morto por conspirar contra Hitler. A crítica ao Estado repressivo da Alemanha permeou todo o capítulo, tanto é que Frei Betto chegou a comparar o Muro de Berlim às muralhas de uma prisão.

"Pato laqueado" e "Tomates com açúcar" tratam da visita de Frei Betto e dos irmãos Boff à China, entre setembro e outubro de 1988. Neles, Frei Betto relata detalhadamente a cultura, a organização social, política e religiosa da China, onde os cristãos eram a minoria da população. Os relatos pontuaram muito as especificidades da sociedade chinesa, pouco conhecida no Ocidente e resultante do imperialismo ocidental.

“Chuletas com batatas" celebrou os 30 anos da Revolução Cubana, em janeiro de 1989, ocasião em que se reuniu com militantes de diversos movimentos socais, e também com Lula e sua a comitiva, na primeira campanha presidencial em que visitaram Cuba. Neste capítulo, ressaltamos a crítica que Frei Betto faz ao regime cubano por publicar, no jornal O Granma, somente a carta de Dom Paulo Evaristo parabenizando pelos 30 anos da Revolução, e de não ter publicado a carta do bispo cubano Jaime Ortega. Frei Betto creditava isso à resistência dos setores empenhados em dificultar o diálogo entre Estado e a Igreja local. Já a carta do Cardeal Arns teve a intenção de propagar, por meio do Granma Interacional, que em Cuba imperava plena liberdade religiosa.

"Em o joio e o trigo", Frei Betto refletiu sobre a necessidade da esquerda brasileira e da Teologia da Libertação revisar suas concepções de socialismo e dos fundamentos de marxismo, após as mudanças ocorridas no Leste Europeu. Não foi um esforço teórico que separava o joio do trigo, 
mas uma tentativa de restaurar a esperança e abrir um novo horizonte de utopias na luta da classe trabalhadora. Não se pode tapar o sol com a peneira num tempo de crise, mas não seria possível ignorar os avanços sociais. Dever-se-ia considerar a burocratização, a centralização e a supressão do pluralismo político aos fatores principais da crise.

Em "Moqueca de dourado", Frei Betto relata que esteve junto a Leonardo Boff, quando seu pai lhe informou a derrota da Frente Sandinista representada por Daniel Ortega para Violeta Chamorro. A vitória de Chamorro, para Frei Betto, colocava em xeque o mais dramático processo revolucionário conhecido pela história, dificultando ainda mais a lutas de El Salvador e Guatemala. O processo coincidiu com o desmoronamento do socialismo no Leste Europeu, provocando medo nos eleitores por causa da falta de recursos externos para o desenvolvimento. Naquele momento de crise, uma parte do episcopado cubano se reuniu com o cardeal Bernad Law, em Boston, para discutir a conjuntura cubana, o que deixou Fidel e o governo cubano incomodados.

Matilde Zimmermann, professora de História Latino-Americana da Faculdade estadunidense Sarah Lawrence, analisa todo o processo revolucionário durante o século XX na Nicarágua, da qual o sandinismo é fruto, em “A Revolução Nicaraguense”. A derrota surpreendente da FSLN foi creditada com um golpe de misericórdia na revolução. Contudo, Zimmermann (2006, p. 135) afirmava ser o resultado de um processo de rompimento com as massas (coração da revolução), que já vinha ocorrendo com a implantação de uma política econômica mais próxima aos interesses do mundo capitalista, representado pelo FMI, em decorrência do medo de ficar isolado após desmoronamento do socialismo no Leste Europeu.

Frei Betto parece concordar com Zimmermann ao encerrar "O paraiso perdido: nos bastidores do socialismo", com "No Jardim da casa, cebola, alho e verduras", $e$ "Pão que o FMI amassa". O primeiro relata o voo de solidariedade à Cuba, organizado por Leonardo Boff, Chico Buarque, Fernando Morais e Eric Nepomuceno, em 1991.

Afirma que a Frente Sandinista se tornou, para a maioria da população, um partido no poder que não expressava mais a demandas populares, com o passar do tempo. O militante, companheiro era agora o dirigente, 
que ocupava destaque nas estruturas do poder, e a Nicarágua não contava, como Cuba, com o apoio econômico de uma grande potência. A retomada da construção do socialismo dependia, nessa medida, da capacidade de retornar às bases e tornar o projeto sedutora utopia: "o povo quer pão e paz, entremeado de diversão e religião” (BETTO, 1993, p. 409).

"O Paraíso Perdido", para além de suas decepções pontuais, foi um conjunto do inventário da decepção maior. Aberto sob o prenúncio da vitória sandinista, finalizou com o voo de solidariedade à Cuba, impactado com a derrota de Daniel Ortega para Violeta Chamorro na Nicarágua, em 1990. Contudo, "O paraíso perdido" não foi um hino fúnebre do socialismo, mas buscou compreender seus erros e acertos. Foi, em realidade, um ato de esperança alimentado por postura agregativa dos ideários cristãos de esquerda (COSTA, 2012, p. 301-302.).

No livro, Frei Betto dialogou com seu caro Teófilo, seguindo o modelo cristão do Novo Testamento, adotando os gestos e formatos dos textos do evangelho de Lucas e dos Atos dos Apóstolos. Betto não ofereceu maiores informações sobre o seu Teófilo. A hipótese levantada por Marcelo Thimoteo da Costa (2013, p. 286-292) é que, ao dedicar ao livro ao jornalista e ativista político Paulo Vannuchi'5, elegeu este como o seu novo Teófilo, hipótese muito palpável, já que Frei Betto dedicara o livro a Paulo Vannuchi nas páginas de pré-índices.

Frei Betto é, com certeza, o teólogo da liberação que manteve contato mais direto com o mundo do socialismo real. Diante disso, refletiu e criticou os erros do sistema socialista real, especialmente no que tange à supressão da democracia e da liberdade religiosa. Contudo, Frei Betto analisou e criticou também a postura intransigente da Igreja Católica perante o ideário marxista. Para ele, mais importante que as divergências de crença, são as convergências para a união, e as lutas para construir uma sociedade justa, verdadeiramente democrática e pluralista.

\footnotetext{
15 Paulo Vannuchi foi ministro dos Direitos Humanos entre 2005 e 2011. Idealizador da Comissão da Verdade, foi eleito em2013 para uma vaga representando o Brasil na Comissão Interamericana de Direitos Humanos da Organização dos Estados Americanos. Mais informações em: www.valor.com.br/internacional/3153320/paulo-vannuchi-eeleito-para-comissao-de-direitos-humanos-da-oea. Acesso em: 27 jan. 2016.
} 


\section{Referências}

AYERBE, L. F. A Revolução Cubana. São Paulo: UNESP, 2004.

COSTA, M. T. A União Soviética segundo Frei Betto. In: RODRIGUES, C. M.; PAULA, C. J. (org.). Intelectuais e militância católica no Brasil. Cuiabá: EdUFMT, 2012, p. 278-297.

HOBSBAWM, E. Era dos Extremos: o breve século XX (1914-1991). São Paulo: Companhia das Letras, 2006.

LÖWY, M. Marxismo e Teologia da Libertação. São Paulo: Cortez, 1991.

SIRINELLI, J.-F. Os intelectuais. In: RÉMOND, R. (org.). Por uma história política. Rio de Janeiro: FGV, 2003, p. 231-270.

SERBIN, K. P. Padres, celibato e conflito social: uma história da Igreja Católica no Brasil. São Paulo: Companhia das Letras, 2008.

ZIMMERMANN, M. A Revolução Nicaraguense. São Paulo: EdUNESP, 2006.

\section{Fontes}

BETTO, F. Cristianismo e marxismo. $2^{\mathrm{a}}$ ed. Petrópolis: Vozes. 1986.

. Fidel e a religião conversa com Frei Betto. $5^{\mathrm{a}}$ ed. São Paulo: Brasiliense, 1985 .

. O paraíso perdido: nos bastidores do socialismo. $2^{\mathrm{a}}$ ed. São Paulo: Geração Editorial, 1993.

Rocco, 2015.

. O paraíso perdido: viagens ao mundo socialista. Rio de Janeiro:

Recebido em 12 de março de 2017. Aprovado em 03 de abril de 2017. 